\section{BRAZIULIAN JOURNAL}

OF MEDICAL AND BIOLOGICAL RESFARCH

www.bjournal.com.br
ISSN 0100-879X

Volume 43 (3) 182-267 March 2011

BIOMEDICAL SCIENCES

AND

CLINICAL INVESTIGATION

Braz J Med Biol Res, March 2011, Volume 44(3) 212-216

doi: 10.1590/S0100-879X2011007500011

Increased expression of keratinase and other peptidases by Candida parapsilosis mutants

T.R. Duarte, S.S. Oliveira, A. Macrae, S.M.L. Cedrola, A.M. Mazotto, E.P. Souza, A.C.N. Melo and A.B. Vermelho

The Brazilian Journal of Medical and Biological Research is partially financed by

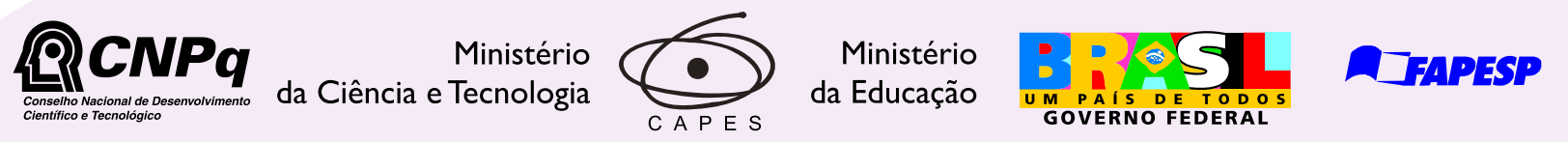

Institutional Sponsors
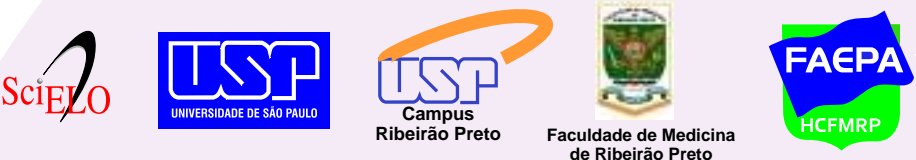

de Ribeirão Predic
Ministério

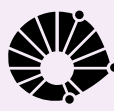

$\oplus$ SHIMADZU

GE Healthcare
Hotsite of proteomics metabolomics developped by:

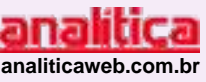




\title{
Increased expression of keratinase and other peptidases by Candida parapsilosis mutants
}

\author{
T.R. Duarte, S.S. Oliveira, A. Macrae, S.M.L. Cedrola, A.M. Mazotto, \\ E.P. Souza, A.C.N. Melo and A.B. Vermelho
}

Laboratório Proteases de Microrganismos, Departamento de Microbiologia Geral, Instituto de Microbiologia Paulo de Góes, Universidade Federal do Rio de Janeiro, Rio de Janeiro, RJ, Brasil

\begin{abstract}
Keratinases are enzymes of great importance involved in pathogenic processes of some fungi. They also have a widespread ecological role since they are responsible for the degradation and recycling of keratin. On the one hand, studying them furthers our knowledge of pathogenicity mechanisms, which has important implications for human health, and on the other hand, understanding their ecological role in keratin recycling has biotechnological potential. Here, a wild-type keratinolytic Candida parapsilosis strain isolated from a poultry farm was treated with ethyl methanesulfonate in order to generate mutants with increased keratinase activity. Mutants were then cultured on media with keratin extracted from chicken feathers as the sole source of nitrogen and carbon. Approximately 500 mutants were screened and compared with the described keratinolytic wild type. Three strains, H36, 17 and J5, showed enhanced keratinase activity. The wild-type strain produced $80 \mathrm{U} / \mathrm{mL}$ of keratinolytic activity, strain $\mathrm{H} 36$ produced $110 \mathrm{U} / \mathrm{mL}$, strain $17,130 \mathrm{U} / \mathrm{mL}$, and strain $\mathrm{J} 5,140 \mathrm{U} / \mathrm{mL}$. A $70 \%$ increase in enzyme activity was recorded for strain J5. Enzymatic activity was evaluated by zymograms with proteic substrates. A peptidase migrating at 100 $\mathrm{kDa}$ was detected with keratin, bovine serum albumin and casein. In addition, a peptidase with a molecular mass of $50 \mathrm{kDa}$ was observed with casein in the wild-type strain and in mutants H36 and J5. Gelatinase activity was detected at $60 \mathrm{kDa}$. A single band of $35 \mathrm{kDa}$ was found in wild-type $C$. parapsilosis and in mutants with hemoglobin substrate.
\end{abstract}

Key words: Candida parapsilosis; Keratinase; Ethyl methanesulfonate; Mutants

\section{Introduction}

Keratin is the major structural protein of feathers, skin and wool (1), is insoluble in water and has high mechanical stability and resistance to proteolysis $(1,2)$. Keratin stability results from a high degree of cross-linking of disulfide bonds, hydrogen bonding and hydrophobic interactions. Despite their stability, keratins do not accumulate in nature and can be hydrolyzed by some microorganisms (3). Feathers, which are a byproduct of commercial poultry production, may represent a waste problem and consequently need adequate management (4). Since feathers are almost pure protein (keratin), they are potentially a less expensive alternative source of protein for animal feed. Feathers can be converted to feather meal via physical and chemical treatments and is used as animal fodder. Conversion generally requires significant energy inputs and also destroys certain amino acids (5). It follows that degradation of feather keratin by microorganisms represents an alternative method to im- prove the nutritional value of feather waste and to prevent environmental contamination (6). Keratinolytic enzymes are produced by fungi, the actinomycetes, and other bacteria and have been frequently isolated from soils $(7,8)$. The industrial potential for keratinases is linked to recycling keratin-containing wastes from the leather, detergent and textile industries (9). Although keratinolytic activity is believed to be widespread in fungi, particularly yeasts, there have been relatively few studies demonstrating this. An aspartic peptidase keratinase from Candida albicans has been described (10), indicating that yeasts are a group with largely unexplored potential.

Yeast strains of the genus Candida are often the main pathogens that cause systemic infections in immunosuppressed patients, particularly HIV-positive and transplanted patients. Studies have shown that $C$. albicans is the species most frequently isolated in these cases $(11,12)$. On the basis

Correspondence: A.B. Vermelho, Laboratório Proteases de Microrganismos, Departamento de Microbiologia Geral, Instituto de Microbiologia Paulo de Góes, Bloco I, CCS, UFRJ, 21941-590 Rio de Janeiro, RJ, Brasil. Fax: +55-21- 2560-8344.

E-mail: abvermelho@micro.ufrj.br

Received April 4, 2010. Accepted January 10, 2011. Available online January 28, 2011. Published March 7, 2011. 
of these findings and of the overall increase in the number of infections caused by Candida spp, there is increased interest in understanding the factors that control yeast-host cell interactions. Among these factors are the peptidases whose physiological role during the microorganism-host cell interaction can be the degradation of mucus and cell walls, facilitating pathogen invasion. Other roles include the degradation of host proteins for nutrition and degradation of proteins involved in the host defense system associated with lymphocytes and macrophages (13). Previous clinical studies have described the production of Candida peptidases closely connected with environmental factors and have described the production of these peptidases as virulence factors for these microorganisms (14). In 1993, Fusek et al. (15) described two aspartic peptidases of $C$. parapsilosis with the capacity to degrade bovine serum albumin (BSA) and hemoglobin. In the present study, we found that these yeasts can also be isolated outside clinical environments and that they continue to produce peptidases that can degrade residues of biotechnological/ecological importance.

In view of the industrial interest in these enzymes, methods have been developed to explore their potential. One route involves recombinant DNA technology and genetic engineering. This approach has been instrumental in converting many biological functions into industrialized processes. The isolation and cloning of keratinase genes is one pathway that ensures improved enzyme yields (16). Another method, also reported here, is bioprospection from novel habitats and mutagenesis (17). Mutagenesis is a quick and inexpensive way to generate novel strains, some of which are high yielding enzyme producers $(18,19)$. In the present study, a wild-type keratinolytic C. parapsilosis strain (20) was selected for mutagenesis and its increased keratinolytic activity is reported.

\section{Material and Methods}

\section{Chemicals \\ Gelatin, casein, hemoglobin, and BSA were obtained from Merck (Germany). The reagents used for electrophore- sis were purchased from Amersham Life Science (England). Yeast extract broth was obtained from Oxoid Ltd. (England). All other reagents were of analytical grade.}

\section{Yeast strain}

The wild-type keratinolytic C. parapsilosis yeast strain used in this study was collected from poultry waste and was isolated on keratin agar and identified (20). Briefly, strains were incubated in tubes containing $0.5 \%$ yeast extract, $0.5 \%$ peptone, $2 \% \mathrm{KCl}$, and $2 \%$ sucrose solution, in a total volume of $5 \mathrm{~mL}$, at $28^{\circ} \mathrm{C}$ for 4 days. Strains were then streaked on keratin agar and single colonies screened for their ability to grow in phosphate-buffered saline (PBS; $150 \mathrm{mM} \mathrm{NaCl,} 20$ $\mathrm{mM}$ phosphate buffer, $\mathrm{pH} 7.2$ ) supplemented with $1 \%$ feather keratin for 20 days at $28^{\circ} \mathrm{C}$. Yeast strains were maintained in PBS (150 mM NaCl, 20 mM phosphate buffer, pH 7.0) supplemented with $1 \%$ feather keratin.

\section{Culture media}

Keratin agar medium (0.2 $\mathrm{M} \mathrm{Na}_{2} \mathrm{HPO}_{4}, 0.1 \mathrm{M}$ citric acid, $0.01 \%$ yeast extract, and $1 \%$ feather keratin substrate) was used for screening the yeasts on plates. Sabouraud broth medium $[2 \%$ glucose $(\mathrm{w} / \mathrm{v}) ; 1 \%$ peptone $(\mathrm{w} / \mathrm{v}) ; 0.5 \%$ yeast extract $(\mathrm{w} / \mathrm{v})$ ] was used for yeast preparations.

\section{Mutagenesis and screening}

The C. parapsilosis strains were grown in $10 \mathrm{~mL} \mathrm{Sa-}$ bouraud broth medium at $37^{\circ} \mathrm{C}$ for $24 \mathrm{~h}$, after which $3 \%$ ethyl methanesulfonate (EMS) was added and incubated at $37^{\circ} \mathrm{C}$ for $1 \mathrm{~h} \mathrm{(21).} \mathrm{Cells} \mathrm{were} \mathrm{then} \mathrm{centrifuged} \mathrm{at} 2800 \mathrm{~g}$ for $15 \mathrm{~min}$ and washed with sterile saline. Successive serial dilutions were prepared and $0.1-\mathrm{mL}$ aliquots were spread on Sabouraud agar medium. Mutant colonies of C. parapsilosis that appeared after $48 \mathrm{~h}$ of incubation at $37^{\circ} \mathrm{C}$ were selected. Colonies were streaked on keratin agar medium for 20 days. Plates were stained with Coomassie blue and colonies surrounded by large clear halos were selected for quantitative keratinase assays.

\section{Feather keratin substrate}

Chicken feathers obtained from poultry waste were washed with water and detergent and then dried at $60^{\circ} \mathrm{C}$ overnight. Lipids were removed by chloroform:methanol $(1: 1, v / v)$ washes and feathers were dried again at $60^{\circ} \mathrm{C}$. Keratin powder was obtained from $10 \mathrm{~g}$ lipid-free dried feathers and heated in a reflux condenser at $100^{\circ} \mathrm{C}$ for 80-120 min with $500 \mathrm{~mL}$ DMSO. Keratin was then precipitated by adding two volumes of acetone and maintained at $4^{\circ} \mathrm{C}$ for 24-48 $\mathrm{h}$. The keratin precipitates were collected by centrifugation (2000 $\mathrm{g}$ for $15 \mathrm{~min}$ ) twice, washed twice with distilled water, and dried at $4^{\circ} \mathrm{C}$. The keratin powder thus produced served as a substrate for keratin agar plates, zymograms and for spectrophotometric analysis. The method used here to produce keratin powder was described by Wawrzkiewicz et al. (22).

\section{Quantitative keratinase assay}

Keratinolytic activity was measured using keratin powder as a substrate soluble in a buffered system. Feather keratin substrate $(10 \mathrm{mg})$ was incubated with $1.5 \mathrm{~mL}$ phosphate buffer, $\mathrm{pH} 7.4$, and $1.0 \mathrm{~mL}$ cell-free culture supernatant (crude enzyme) for $1 \mathrm{~h}$ at $37^{\circ} \mathrm{C}$. The enzyme reaction was

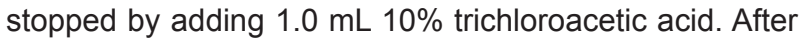
a further $30 \mathrm{~min}$ at $4^{\circ} \mathrm{C}$, the tubes were centrifuged for 15 min at $2500 \mathrm{~g}$ in a refrigerated centrifuge at $4^{\circ} \mathrm{C}$ and absorbance was measured in the supernatant at $280 \mathrm{~nm}$. One unit of keratinolytic activity was the amount of enzyme that caused a change of absorbance of 0.01 at $280 \mathrm{~nm}$ within $1 \mathrm{~h}$ at $37^{\circ} \mathrm{C}(23,24)$. 


\section{Substrate gel electrophoresis}

Keratinases were assayed and characterized by substrate gel electrophoresis. The gel consisted of $12.5 \%$ sodium dodecyl sulfate-polyacrylamide with co-polymerized keratin feather powder (20), 0.1\% (w/v) gelatin, casein, BSA, or hemoglobin incorporated as substrate (25-27). After electrophoresis, gels were incubated for $48 \mathrm{~h}$ at $37^{\circ} \mathrm{C}$ in $50 \mathrm{mM}$ phosphate buffer, $\mathrm{pH}$ 5.5. To detect the presence of peptidases, gels were stained for $1 \mathrm{~h}$ with $0.2 \%$ Coomassie blue R-250 in methanol-acetic acid-water (50:10:40) and destained in the same solvent. Gels were then dried, scanned and processed digitally. Phosphorylase b (94 kDa), BSA (67 kDa), ovalbumin (43 kDa), carbonic anhydrase (30 kDa), soybean trypsin inhibitor (20.1 kDa), and $\alpha$-lactalbumin (14.4 kDa) were used as molecular mass standards (GE Healthcare, Brazil).

\section{Results}

\section{Mutagenesis}

Approximately 500 colonies were analyzed and compared to the wild-type keratinase-producing C. parapsilosis strain. Comparisons were made after growth on keratin agar followed by staining with Coomassie blue. Three mutant strains produced larger degradation halos than the wild-type strain and were identified as H36, 17 and J5 (Figure 1). The enzymatic assay of Grzywnowicz et al. (23) was used to quantify and compare differences in the enzyme activities. The keratinolytic activity of strain $\mathrm{J} 5$ was a serine peptidase $70 \%$ higher than that of the wild-type strain (Figure 2).

\section{Enzymatic activity of mutants on gelatin, keratin, casein, BSA, and hemoglobin}

Supernatant solutions from the three mutant strains were concentrated 20 times by dialysis using a 9000-Da membrane and PEG 4000. The proteolytic profiles were analyzed by zymography using keratin and gelatin as substrates. A band with a molecular mass of $60 \mathrm{kDa}$ was observed on the gel with gelatin and a band of $100 \mathrm{kDa}$ was observed for keratin (Figure 3). Zymograms using BSA, hemoglobin and casein as substrates also showed bands. Bands of $100 \mathrm{kDa}$ were observed for BSA, bands of $35 \mathrm{kDa}$ for hemoglobin, and two bands, 100 and $50 \mathrm{kDa}$, were observed for casein (Figure 3).

\section{Discussion}

We have recently reported the isolation of a keratinolytic wild-type yeast that produced an extracellular serine peptidase with keratinolytic activity (20). In the present study, mutagenesis was used as a tool to modify that original wild-type strain and resulted in a collection of $\sim 500$ C. parapsilosis mutant strains. The collection was screened and treatment with EMS yielded three strains with higher keratinolytic activity than the wild type. EMS was used by Shu-Fei et al. (28) to increase the production of $\beta$-mannanase from Aspergillus niger LW-1. Nanmori et al. (29) used nitrosoguanidine to increase exo- $\beta$-amylase production from a Bacillus cereus mutant. The present

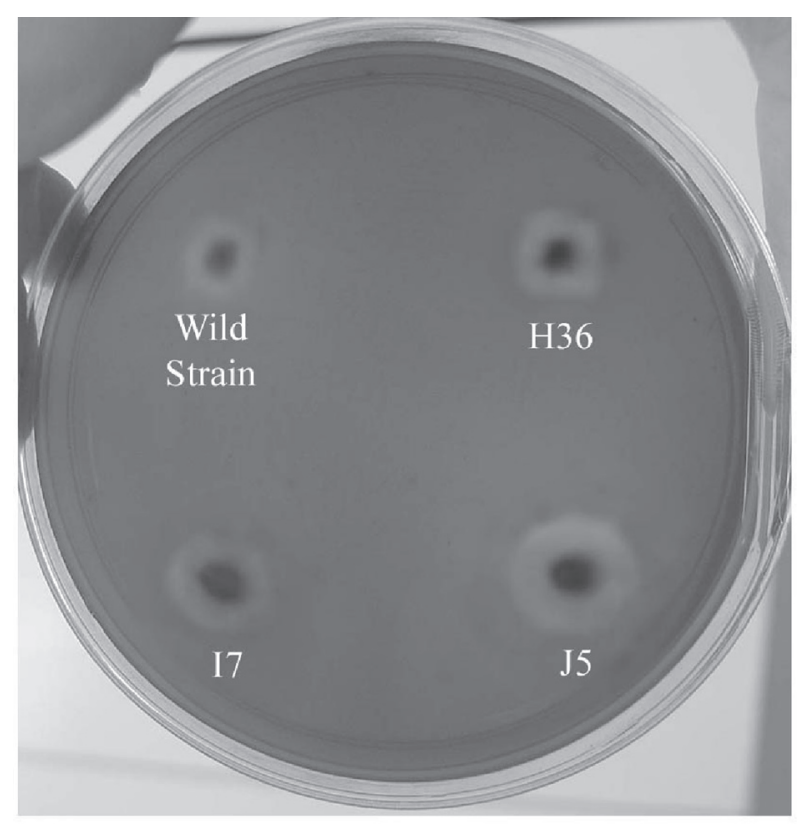

Figure 1. Extracellular keratinase activity on agar plates containing feather keratin as substrate (for details, see Material and Methods). The plate was stained with Coomassie blue. Candida parapsilosis is the wild strain and $17, \mathrm{H} 36$ and $\mathrm{J} 5$ are mutants obtained from the $C$. parapsilosis with $3 \%$ ethyl methanesulfonate. Clear zones/halos correspond to degradation of keratin.

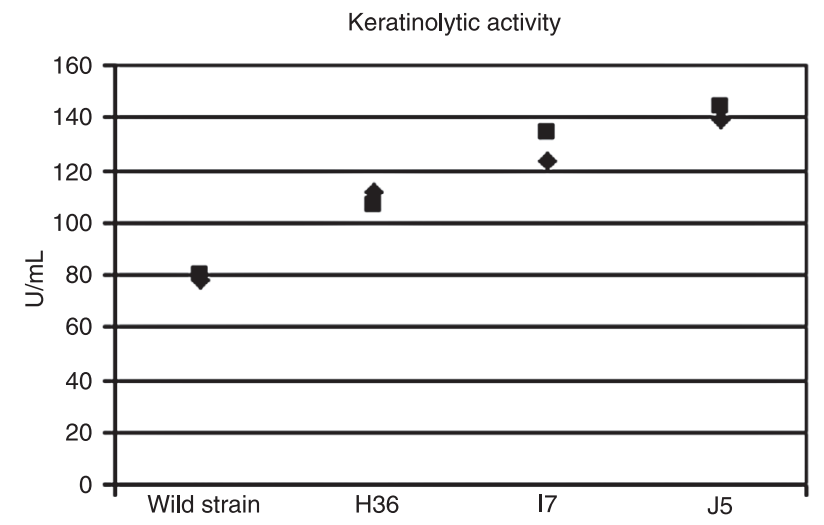

Figure 2. Keratinolytic activity showing higher activity of mutants compared to the wild strain $(N=2)$. Keratinase was measured using feather keratin as substrate $(10 \mathrm{mg})$ incubated with $1.5 \mathrm{~mL}$ phosphate buffer, $\mathrm{pH} 7.4$, and $1.0 \mathrm{~mL}$ cell-free culture supernatant containing $0.2 \mathrm{mg}$ protein (crude enzyme) for $1 \mathrm{~h}$ at $37^{\circ} \mathrm{C}$. Results are shown for two independent experiments indicated by lozenges and squares. One unit of keratinolytic activity was the amount of enzyme that caused a change of absorbance of 0.01 at $280 \mathrm{~nm}$ within $1 \mathrm{~h}$ at $37^{\circ} \mathrm{C}$. 

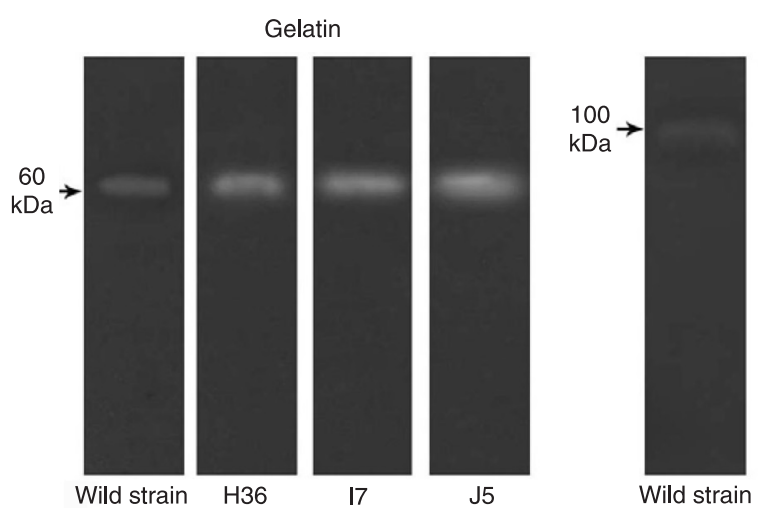

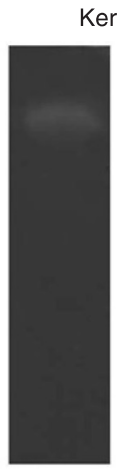

H36
Keratin

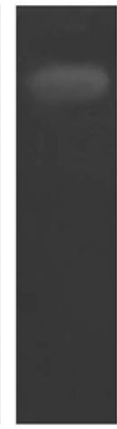

17

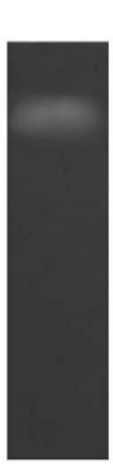

J5

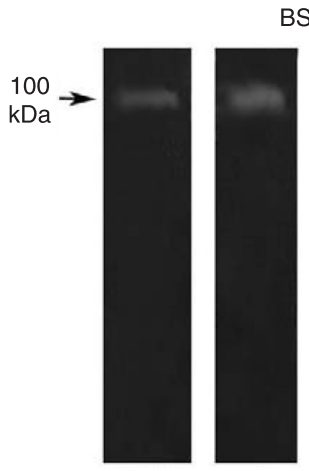

Wild strain $\mathrm{H} 36$
BSA

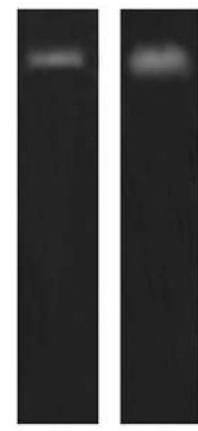

J5

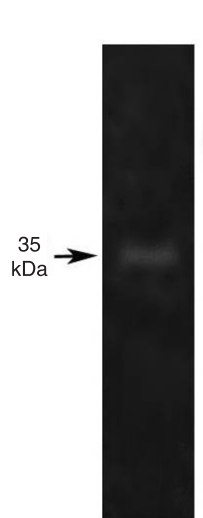

Wild strain

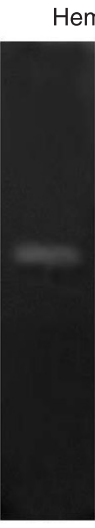

$\mathrm{H} 36$ emoglobin

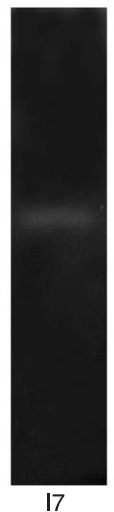

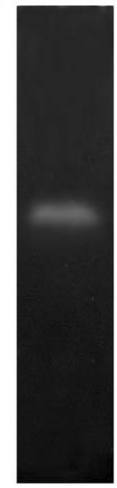

J5

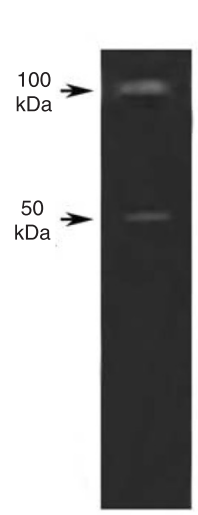

Wild strain
Casein

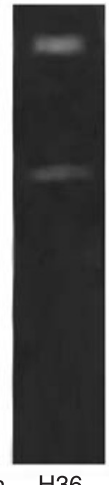

H36

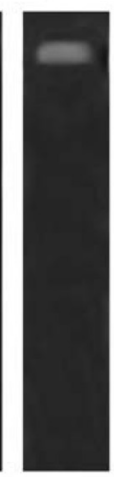

17

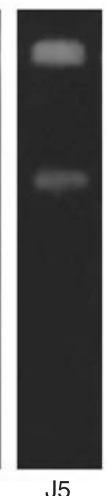

J5

Figure 3. Zymograms showing proteolytic activity using gelatin, keratin, bovine serum albumin (BSA), hemoglobin, and casein.

study is the first report using EMS to induce mutagenesis in favor of keratinase production. We found that this simple method provided strains that produced more enzyme than the wild type from which it was derived.

Cai et al. (17) reported the successful use of chemical mutagenesis to increase the expression of keratinase in Bacillus subtilis using N-methyl-N-nitro-N-nitrosoguanidine. In their study, a mutant strain called KD-N2 showed twice the activity of their wild strain. Our results with a yeast, rather than a bacterium, are similar to those of Cai et al. (17). Cai et al. inferred keratinase activity based on agar media with casein and not keratin because of the general lack of commercially available keratin in powder form.

From the zymograms shown in Figure 3, we can see that all 4 yeast strains produced a $100-\mathrm{kDa}$ band with keratin and BSA. Specific substrates will be needed to determine if these are the same substrate (17).

The data in Figure 3 suggest that the enzyme activity produced by the EMS mutants resulted in brighter bands on the zymograms and presumably increased peptidase activity compared to the wild-type strain.

It is interesting to note that, although potentially pathogenic, this strain was isolated from residues from a local poultry farm. It is possible that this yeast strain belongs to a microbial consortium of keratin decomposers adapted to feather degradation and representing a source of other strains of biotechnological interest.

\section{Acknowledgments}

We would like to thank the technical assistance of Ms. Denise da Rocha de Souza, supported by fellowships from MCT/CNPq. Research supported by CAPES, FAPERJ, MCT/CNPq, Conselho de Ensino para Graduados e Pesquisas (CEPG/UFRJ), and Fundação Universitária José Bonifácio (FUJB). 


\section{References}

1. Bradbury $\mathrm{JH}$. The structure and chemistry of keratin fibers. Adv Protein Chem 1973; 27: 111-211.

2. Parry DA, North AC. Hard alpha-keratin intermediate filament chains: substructure of the $\mathrm{N}$ - and $\mathrm{C}$-terminal domains and the predicted structure and function of the C-terminal domains of type I and type II chains. J Struct Biol 1998; 122: 67-75.

3. Brandelli A. Bacterial keratinases: useful enzymes for bioprocessing agroindustrial wastes and beyond. Food Bioprocess Technol 2008; 1: 105-116.

4. Shih $\mathrm{JCH}$. Recent development in poultry waste digestion and feather utilization - A review. Poultry Sci 1993; 72: 16171620.

5. Papadoulos MC, Ketelaars EH. Effects of processing time and moisture content on amino acid composition and nitrogen characteristics of feather meal. Anim Feed Sci Technol 1986; 14: 279-290.

6. Park GT, Son HJ. Keratinolytic activity of Bacillus megaterium F7-1, a feather-degrading mesophilic bacterium. Microbiol Res 2009; 164: 478-485.

7. Kaul S, Sumbali G. Keratinolysis by poultry farm soil fungi. Mycopathologia 1997; 139: 137-140.

8. Riffel A, Brandelli A. Keratinolytic bacteria isolated from feather waste. Braz J Microbiol 2006; 37: 395-399.

9. Li J, Shi PJ, Han XY, Meng K, Yang PL, Wang YR, et al. Functional expression of the keratinolytic serine protease gene sfp2 from Streptomyces fradiae var. k11 in Pichia pastoris. Protein Expr Purif 2007; 54: 79-86.

10. Hattori M, Yoshiura K, Negi M, Ogawa H. Keratinolytic proteinase produced by Candida albicans. Sabouraudia 1984; 22: 175-183.

11. Krcmery V, Barnes AJ. Non-albicans Candida spp causing fungaemia: pathogenicity and antifungal resistance. J Hosp Infect 2002; 50: 243-260.

12. Cheng MF, Yu KW, Tang RB, Fan YH, Yang YL, Hsieh KS, et al. Distribution and antifungal susceptibility of Candida species causing candidemia from 1996 to 1999. Diagn Microbiol Infect Dis 2004; 48: 33-37.

13. Hube B. Extracellular proteinases of human pathogenic fungi. Contrib Microbiol 2000; 5: 126-137.

14. Santos ALS, Carvalho IM, Silva BA, Portela MB, Alviano CS, Soares RMA. Secretion of serine peptidase by a clinical strain of Candida albicans: influence of growth conditions and cleavage of human serum proteins and extracellular matrix components. FEMS Immunol Med Microbiol 2005; 46: 209-220.

15. Fusek M, Smith EA, Monod M, Foundling SI. Candida parapsilosis expresses and secretes two aspartic proteinases. FEBS Lett 1993; 327: 108-112.

16. Gupta R, Ramnani P. Microbial keratinases and their pro- spective applications: an overview. Appl Microbiol Biotechnol 2006; 70: 21-33

17. Cai CG, Lou BG, Zheng XD. Keratinase production and keratin degradation by a mutant strain of Bacillus subtilis. $J$ Zhejiang Univ Sci B 2008; 9: 60-67.

18. Tan TW, Zhang M, Wang BW, Ying CH, Deng L. Screening of high lipase producing Candida sp and production of lipase by fermentation. Process Biochem 2006; 39: 459-465.

19. Wang CL, Li DF, Lu WQ, Wang YH, Lai CH. Influence of cultivating conditions on the alpha-galactosidase biosynthesis from a novel strain of Penicillium sp in solid-state fermentation. Lett Appl Microbiol 2010; 39: 369-375.

20. Vermelho AB, Mazotto AM, de Melo AC, Vieira FH, Duarte TR, Macrae A, et al. Identification of a Candida parapsilosis strain producing extracellular serine peptidase with keratinolytic activity. Mycopathologia 2010; 169: 57-65.

21. Lindegren G, Hwang YL, Oshima Y, Lindegren CC. Genetical mutants induced by ethyl methanesulfonate in Saccharomyces. Can J Genet Cytol 1965; 7: 491-499.

22. Wawrzkiewicz K, Lobarzewski J, Wolski T. Intracellular keratinase of Trichophyton gallinae. J Med Vet Mycol 1987; 25: 261-268.

23. Grzywnowicz G, Lobarzewski J, Wawrzkiewicz K, Wolski T. Comparative characterization of proteolytic enzymes from Trichophyton gallinae and Trichophyton verrucosum. J Med Vet Mycol 1989; 27: 319-328.

24. Mazotto AM, Cedrola SM, Lins U, Rosado AS, Silva KT, Chaves JQ, et al. Keratinolytic activity of Bacillus subtilis AMR using human hair. Lett Appl Microbiol 2010; 50: 8996.

25. Heussen C, Dowdle EB. Electrophoretic analysis of plasminogen activators in polyacrylamide gels containing sodium dodecyl sulfate and copolymerized substrates. Anal Biochem 1980; 102: 196-202.

26. Chaia AA, De Simone G, Petinate SDG, Lima APCA, Branquinha $M H$, Vermelho $A B$. Identification and properties of two extracellular proteases from Brevudimonas diminuta. Braz J Microbiol 2000; 31: 25-29.

27. Lopes BG, Santos AL, Bezerra CC, Wanke B, Dos Santos LM, Nishikawa MM, et al. A 25-kDa serine peptidase with keratinolytic activity secreted by Coccidioides immitis. Mycopathologia 2008; 166: 35-40.

28. Shu-Fei Z, Jia-Huan S, Min-Chen W, Jin-Ping S, Jian-Fang L. Mutation breeding of Aspergillus niger strain LW-1 for high-yield $\beta$-mannanase production. J Agric Biotec 2008; 16: $346-350$

29. Nanmori T, Numata Y, Shinke R. Isolation and characterization of a Bacillus cereus mutant strain hyperproductive of exo-beta-amylase. Appl Environ Microbiol 1987; 53: 768771. 